\title{
Faculty Diversity at the Indian Institutes of Management (IIMs): A Preliminary Snapshot
}

\author{
Siddharth Joshi \& Deepak Malghan \\ Centre for Public Policy, Indian Institute of Management Bangalore \\ Bannerghatta Road, Bengaluru, 560076 \\ [siddharth.joshi09, dmalghan]@iimb.ernet.in
}

January $28^{\text {th }} 2017^{\text {t }}$

\begin{abstract}
$\underline{\text { ABSTRACT }}$
We present a preliminary snapshot of the social composition of faculty at the Indian Institutes of Management (IIMs). We find that the faculty body at these institutions is drawn from a very narrow spectrum of Indian society. We argue that by not paying attention to faculty diversity, IIMs engender a crisis of relevance and legitimacy. The proposed legislation that will convert IIMs into degree granting institutions offers a canvas for public deliberation on the question of social diversity at IIMs.
\end{abstract}

Keywords: IIMs, Affirmative Action, Diversity

\section{Introduction}

On 24th Jan 2017, the union cabinet cleared the way for the introduction of the Indian Institutes of Management Bill in the parliament. ${ }^{1}$ An earlier version of this draft legislation that was first mooted in 2015 had run into controversy over potential breach of institutional autonomy. The Indian Institutes of Management (IIMs) argued that the 2015 draft amounted to regulatory overreach that could stifle the academic environment at IIMs. ${ }^{2}$ In the ensuing public debate, a central predicament for contemporary universities (especially public institutions) - social diversity - has received scant attention even as the larger public discourse in the past year has focussed on making our universities more diverse, accessible, and inclusive. In this brief snapshot, we present data detailing the lack of social diversity in faculty composition at IIMs. Institutional autonomy is necessarily tied to social accountability, and we argue here that the neglect of social diversity at IIMs severely undermines their social legitimacy as public institutions. In this brief commentary, we do not offer specific prescriptions, or even strategies for amelioration. A deliberation on specific interventions is perhaps futile, and certainly premature in the absence of a clear normative commitment to faculty diversity at IIMs. We defend faculty diversity as an important constituent of IIMs' academic mission as well as their larger social compact.

\section{Current Snapshot}

The data on faculty composition that we present here is collated from responses obtained under the Right to Information Act 2005 (RTI). At the time we filed our RTI requests, thirteen IIMs were fully functional with an autonomous and permanent faculty body (June 2016). The data that we obtained using RTI requests at both the Ministry of Human Resource Development of the Government of India (MHRD), and individual IIMs is presented in Table-1. We have data for 233 faculty members across six IIMs. The four leading IIMs

\footnotetext{
¥We thank Amit Basole and Gopal Guru for insightful discussions. The authors are solely responsible for data and interpretation presented here. All opinions expressed here are wholly personal and do not reflect the institutional position(s) of IIM Bangalore where Joshi is a doctoral student and Malghan is a faculty member.
} 
in the country established before 1985, in their respective RTI responses, noted that they do not maintain data on the social groups that their faculty members belong to. Two newer IIMs (Shillong, and Tiruchirapalli) did not respond to our RTI applications. IIM-Udaipur skirted our request for data, but confirmed that they do not have an affirmative action policy for faculty recruitment. While we have actual data for only six out of the thirteen IIMs, anecdotal evidence including informal consultations with colleagues at the remaining seven institutions suggests that the diversity deficit at those institutions is at least as acute.

The IIMs that maintain faculty social group data and responded to our RTI requests also provided incidence data on faculty belonging to the $\mathrm{OBC}$ (other backward classes). However, we have used the three-fold classification of social groups defined by the decennial national census with $\mathrm{OBC}$ numbers added to "others". We make this choice for normative as well as empirical reasons. Briefly, the historical trajectories as well as contemporary circumstances of the $\mathrm{OBC}$ groups are fundamentally different from social groups classified as SC or ST. We present a general defense of faculty diversity at IIMs and our broad arguments are not limited to amelioration of a particular type of diversity deficit. However, any programme to correct the lack of social diversity at IIMs must begin by addressing the near total absence of SC or ST representation among IIM faculty.

\begin{tabular}{|c|c|c|c|c|}
\hline $\begin{array}{l}\text { Institution (year of } \\
\text { establishment) }\end{array}$ & SC & ST & ОТН & TOTAL \\
\hline IIM, Indore (1996) & 0 & 0 & 92 & 92 \\
\hline IIM, Kozhikode (1996) & 1 & 0 & 62 & 63 \\
\hline IIM, Rohtak (2009) & 1 & 0 & 17 & 18 \\
\hline IIM, Raipur (2010) & 0 & 0 & 13 & 13 \\
\hline IIM, Ranchi (2010) & 0 & 0 & 16 & 16 \\
\hline IIM, Kashipur (2011) & 0 & 0 & 31 & 31 \\
\hline $\begin{array}{l}\text { IIM, Calcutta (1961) } \\
\text { IIM, Ahmedabad (1961) } \\
\text { IIM, Bangalore (1973) } \\
\text { IIM, Lucknow (1984) }\end{array}$ & \multicolumn{4}{|c|}{$\begin{array}{l}\text { These institutions do not maintain faculty social } \\
\text { group data (RTI response, June 2016). }\end{array}$} \\
\hline IIM, Udaipur (2011) & \multicolumn{4}{|c|}{$\begin{array}{l}\text { We were unable to determine if IIM-Udaipur } \\
\text { collects such data. The original, and the } \\
\text { appellate response to authors' RTI requests } \\
\text { neither included data on census caste categories } \\
\text { nor a confirmation that the institute does not } \\
\text { collect such data (June 2016). }\end{array}$} \\
\hline IIM, Shillong (2007) & \multirow{2}{*}{\multicolumn{4}{|c|}{$\begin{array}{l}\text { These institutions have not responded to authors' } \\
\text { RTI request made in May } 2016 \text { (as of January } \\
25^{\text {th }} 2017 \text { ). }\end{array}$}} \\
\hline IIM, Tiruchirapalli (2011) & & & & \\
\hline $\begin{array}{l}\text { Totals (excluding no-data, } \\
\text { and no-response) }\end{array}$ & 2 & $\mathbf{0}$ & 231 & 233 \\
\hline
\end{tabular}

TABLE-1 Census-category distribution of faculty at IIMs. Data was obtained through a RTI request filed in May/June 2016. We use the census of India categories (SC = Scheduled Castes; $S T=$ Scheduled Tribes; $O T H=$ All other social groups). Out of the 231 faculty members reported as belonging to "OTH", the six institutions that provided social group data also reported a total of 5 faculty members (across these six institutions) as belonging to the OBC category. 


\section{Future Faculty Pipeline}

The doctoral programs at IIMs (offered at all 13 institutions listed in Table-1) serve as crucibles where future faculty members are forged. A majority of these programs do not have a stated policy on diversity or affirmative action. As of academic year 2017-18, the IIMs at Ahmedabad and Bangalore (both of which have been a significant source of faculty members recruited at newer IIMs in the past several years) do not use any affirmative action mechanisms to inform their admission decisions. To be sure, a traditional reservation model with inflexible numerical quotas is perhaps not desirable and in any case certainly impossible to implement when no more than 1-3 students per year (or sometimes even every alternate year) are admitted into each department. Even when a well-qualified student seeks doctoral admission, she is offered a place only when her broad research interests intersects with current faculty competence and interests. However, neither the central government that provides partial funding for these doctoral programmes (Table -2) nor the individual institutions have an alternate affirmative action program in place. ${ }^{3}$ While we do not have data on the social composition of doctoral students at IIMs, anecdotal evidence suggests that in the absence of a strong commitment to diversity, these programmes mirror the monochromatic composition of the faculty body. Fourteen new IIMs have been set up in last eight years, and the six older IIMs set up in the twentieth century are expanding their student intake. The doctoral programmes at the three oldest IIMs will continue to be one of the most important sources of scholars who will support this expansion. The lack of social diversity in these doctoral programmes will result in continued propagation of the status quo as the IIM system expands over the next several years.

\begin{tabular}{|l|c|c|c|}
\hline \multirow{2}{*}{ Financial Year } & \multicolumn{3}{|c|}{$\begin{array}{c}\text { Government of India Grants to Doctoral Programmes at IIMs (in lakhs of rupees } \\
\text { per financial year) }\end{array}$} \\
\cline { 2 - 4 } & IIM Ahmedabad & IIM Bangalore & IIM Calcutta \\
\hline $\mathbf{2 0 1 2 - 1 3}$ & 100.96 & 80.36 & 89.2 \\
\hline $\mathbf{2 0 1 3 - 1 4}$ & 63.4 & 0.00 & 0.00 \\
\hline $\mathbf{2 0 1 4 - 1 5}$ & 70.11 & 199.18 & 0.00 \\
$\mathbf{2 0 1 5 - 1 6}$ & NA & 53.92 & 81.27 \\
\hline
\end{tabular}

TABLE-2 Level of recent government support for doctoral programmes (Fellow Programme in Management, or FPM) at the three oldest IIMs. Data for 2115-16 at IIM, Ahmedabad was not available at the time of RTI responses from MHRD (Ministry of Human Resource Development, Government of India) and IIMAhmedabad (June 2016).

\section{Discussion}

An extended meditation on means to address the diversity deficit described by the data presented here is beyond the scope of this brief commentary. However, what is clear from the data presented in Table- 1 is that the status quo is patently indefensible. The snapshot described above represents over half a century of neglect -- willful, or otherwise and needs urgent redressal. While being agnostic about the methods that can potentially begin to reverse the acute diversity deficit, we defend the imperative to do so. We briefly address some of the fundamental theoretical presuppositions related to the nature of caste categories and boundaries that have provided cover for the neglect of social diversity questions at IIMs. Unlike wholly uncritical platitudes in defense of some imagined notion of pristine meritocracy, these are serious objections to both the desirability and possibility of universities being able to adequately address certain forms of diversity deficit. These are conundrums that demand sustained and serious deliberation, and cannot be resolved by partisan grandstanding. Our purpose here is more modest - we merely want to outline why the diversity deficit at IIMs is a "wicked problem", but one that should not be wished away.

Following the triumph of the constructivist paradigm in the social sciences we find ourselves in a position where "instead of describing how an ethnic community travels down the road of history, we now outline how it came into being and later dissolves; instead of observing the everyday workings of an ethnic culture, the 
varying claims to cultural difference are studied." ${ }^{5}$ To be sure, both short-term and long-term evolutionary trajectories of societies share a dialectical relationship with social and political construction of ethnic categories like caste (famously for example, categories used by colonial censuses used to classify Indian society). However, it is important to recognise that constructivism is an epistemological strategy (or even merely an empirical choice) rather than an "ontological statement about the nature of empirical reality". ${ }^{6}$ Liberal opponents of using caste as a legitimate diversity marker argue that any form of caste category based affirmative action only undermines their project of transcending, if not completely erasing these categories. It is argued that any such affirmative action programme opens the door for narrow identity-centred parochial interests to overrun a deliberative academic space. The evident decay and decline of some of India's finest state universities is held up as a cautionary tale. In the hyper-constructivist scheme of things, caste is an entirely constructed category with no ontological stability. To the extent that "annihilation of caste" is a widely shared normative goal, an argument is made that modern institutions like universities can help the cause by diluting caste identities and constructing modern ones that are not as ethnic a category, or as pernicious. $^{7}$

In response to the relative decline of the salience of caste in modern urban settings that is offered as evidence by hyper-constructivists, other social theorists have emphasized that such a transformation is a result of the "conversion of traditional caste capital into secular modern casteless capital [by specific caste groups in] previous generations". ${ }^{8}$ This Bourdieusian argument has been deployed to shed light on the co-evolution of the social life of caste and modern notions of merit. ${ }^{9}$ In his seminal essay, "The Forms of Capital", Pierre Bourdieu had first emphasized how various forms of social and cultural capital are transmutable. ${ }^{10}$ Bourdieu specifically signals out credentialed educational qualification as the "institutionalized state" of cultural capital that is a "product of conversion" of other forms of capital. ${ }^{11}$ In this view, caste is invisible only to those sections of society that have successfully transformed their traditional caste advantages into modern forms of social, cultural, and economic capital. In Bordieu's memorable opening phrase, "[t]he social world is accumulated history" and it has been argued that modern institutions including universities must address the genealogical trajectories of how traditional caste advantages (and disadvantages) are translated in modern settings.

The Bourdieusian capital transmutation diagnosis does not immediately pave the way for resolution of the constructivist dilemma even as it unpacks the inequities underlying the liberal argument. Multitude of India's diverse social groups have for long internalized the "forms of capital" logic so that as the doyen of Indian political science Rajni Kothari presciently observed, "where caste itself becomes a political category, it is futile to argue whether caste uses politics or politics uses caste". ${ }^{12}$ The liberal anathema to caste based affirmative action is predicated on the assertion that academic spaces ought not to become sites for identity battles that punctuate electoral politics.

Beyond broader theoretical objections to any affirmative action policy that uses caste identity as a criterion, a potential loss of institutional autonomy is the central argument that the IIMs have articulated. Affirmative action is immediately equated to state mandated numerical quotas and seen as a slippery slope to even greater state control in other aspects of IIMs' functioning. We are at least as skeptical of state encroachment of academic autonomy as any of our colleagues at IIMs. An institution of higher learning is not, and never should be constituted as an organ of the state. However, autonomy from an interventionist state has seldom been used by IIMs to advance critical academic engagement with business practices or business environments including larger political and societal contexts within which businesses operate. The duplicity of the autonomy argument advanced by activist faculty bodies at IIMs is at least partially driven by broader structural forces in the political economy. The construing of the universities as profit centres has resulted in a corrosive culture at several IIMs. The powerful faculty bodies and boards led by corporate honchos with implicit support from the well-heeled urban class have subverted autonomy for largely self-fulfilling ends. IIMs have been among the first institutions of higher learning in India to fully endorse a fundamental category error that universities around the world have been forced to live with - misconstruing complex integrity problems as incentive design problems. A direct result of this confusion between integrity and incentives is that IIMs are perhaps the only public institutions in the country where faculty demand that they be bribed (incentivized) to do what is definitional to being an academic - thinking about the world around us, 
and producing new knowledge. Every peer-reviewed article published by an IIM faculty is rewarded by a purse that can in some instances dwarf the annual faculty salaries at other public universities in the country. ${ }^{13}$

The substantive autonomy that IIMs have enjoyed has not translated into a steadfast commitment to social diversity or inclusion. Institutional autonomy at public universities is not an unfettered right but a social compact between the institution and the society at large. A fundamental normative commitment to social inclusion is a central legitimating principle underlying any such social compact. Surely, there can be (indeed should be) differences in means to making institutions inclusive, and a single prescription cannot possibly even cover all the IIMs that are disparate in terms of their age, location, focus, legacy, etc. However, the moral fabric underpinning the social compact will have to be twisted, turned, and stretched in scarcely believable ways to not recognize the status quo as anything but illegitimate. IIMs stand at the cusp of becoming full-fledged degree granting public institutions with unmatched autonomy for any Indian university. Any such autonomy must be firmly yoked to a flexible but effective affirmative action programme that can reverse the acute diversity deficit reported here. In absence of such a programme any further autonomy granted to the IIMs can only translate into reproduction of the dominance of entrenched classes.

\footnotetext{
${ }^{1}$ http://pib nic.in/newsite/erelease. aspx?relid=157623 (accessed, 24 th January 2017).

${ }^{2}$ For example, see Rama Bijapurkar, "IIM bill: Degree of unfreedom", The Indian Express, July 13, 2015.

${ }^{3}$ According to information available on respective doctoral admissions web portals, IIMs at Kashipur, Shillong, and Raipur are the only three IIMs with some form of a publicly stated affirmative action policy for doctoral admissions. In its 2015-16 announcement of doctoral admissions (and, unlike 2016-17), IIM-Calcutta had also publicized it compliance with Government of India reservation policy (admissions web sites of IIMC, accessed January $24^{\text {th }}$ 2017). In 2016-17, both the authors of this article worked with the academic administration at IIM-Bangalore (IIMB) on crafting a workable affirmative action policy for IIMB's doctoral programme. However, as of January 2017, the institute is yet to draft such a policy. The official admissions announcement for academic year 2017-18 continues with the practice of previous years where the social or economic background of the applicant is not considered during admissions (http://www.iimb.ernet.in/sites/default/files/fpm-adm-process.pdf, accessed January 25 $5^{\text {th }}$ 2017). However, we are grateful to the faculty committee that oversees the doctoral programme at IIMB for insightful discussions on increasing doctoral student diversity at IIMB.

${ }^{4}$ H.W.J. Rittel and M.M. Webber (1973), "Dilemmas in a General Theory of Planning”, Policy Sciences 4 (155-169).

${ }_{6}^{5}$ A. Wimmer (2012), Ethnic Boundary Making: Institutions, Power, Networks (New York, Oxford University Press), p.2.

${ }^{6}$ ibid, p.3

${ }^{7}$ A review of the debate on whether caste represents an ethnic category is beyond the scope of this brief commentary. For a more general review of how ethnic categories are (ought to be) defined see K. Chandra (2006), "What is Ethnic Identity And Does It Matter?”, Annual Review of Political Science, 9:397-424.

${ }^{8}$ S. Deshpande (2013), “Caste and Castelessness: Towards a Biography of the 'General Category"”, Economic and Political Weekly, XLVIII(15): 32-39.

${ }^{9}$ A. Subramanian (2015), "Making Merit: The Indian Institutes of Technology and the Social Life of Caste", Comparative Studies in Society and History, 57(2):291-322.

${ }^{10}$ P. Bourdieu (1986), “The Forms of Capital”. In. J. Richardson (ed.), Handbook of Theory and Research for the Sociology of Education, (Westport, CT: Greenwood Press), pp. 241-58.

${ }^{11}$ ibid.

${ }^{12}$ R. Kothari (1970), Politics in India. (Boston, MA: Little, Brown and Company).

${ }^{13}$ Disclosure: One of the authors (DM) has been a recipient of these "incentives".
} 